\title{
The effects of a national highway on the Endangered golden-brown mouse lemur Microcebus ravelobensis in Ankarafantsika National Park, Madagascar
}

\author{
Malcolm S. Ramsay, Andriamahery RaZafind Rakoto \\ and SHAWN M. LEHMAN
}

\begin{abstract}
Although roads are often assumed to be barriers to the dispersal of arboreal species, there has been little empirical testing of this assumption. If arboreal animals are unable to cross roads, population subdivision may occur, or resources may become inaccessible. We tested the hypothesis that Route Nationale $4\left(\mathrm{RN}_{4}\right)$, a paved highway, was a barrier to movement and dispersal of the Endangered golden-brown mouse lemur Microcebus ravelobensis in Ankarafantsika National Park, in north-west Madagascar. During June-August 2015 we conducted a capture-mark-recapture study at three sites: two adjacent to $\mathrm{RN}_{4}$ and one within intact forest without a potential barrier. During 2,294 trap nights we captured 120 golden-brown mouse lemurs 1,032 times. In roadside habitats we captured significantly more males than females, whereas the opposite was the case in interior forest habitat. We detected eighteen crossings of highway transects by nine individuals; however, all potential dispersal events involved males. In roadside habitat, movement was significantly inhibited in both males and females. We present some of the first data on the effects of roads on movement patterns in arboreal Malagasy mammals, showing species- and sex-biased effects of roads as dispersal barriers. Our findings indicate that roads may not be complete barriers to dispersal in lemurs. We recommend that conservation managers and scientists examine explicitly the effects of roads and natural arboreal bridges in Madagascar in future studies.
\end{abstract}

Keywords Dispersal, lemur, Madagascar, Microcebus ravelobensis, movement, road ecology, sex-biased effects, vehicular mortality

\section{Introduction}

7 here is an extensive literature on the effects of roads on 1 wildlife and environments (e.g. Forman, 2003; van der

Malcolm S. Ramsay (Corresponding author) and Shawn M. Lehman Department of Anthropology, University of Toronto, Canada

E-mail malcolm.ramsay@mail.utoronto.ca

AndRiAmahery Razafindrakoto Department of Animal Biology, University of Antananarivo, Madagascar

Received 8 April 2017. Revision requested 11 May 2017.

Accepted 11 August 2017. First published online 27 November 2017.
Ree et al., 2015). However, many road ecology studies have focused on terrestrial species in temperate environments, especially in areas with highly developed road infrastructure, such as Europe and North America (Holderegger \& Di Giulio, 2010). These studies have focused on large, paved freeways and finding practical solutions to the problems posed by roads (Smith et al., 2015). Arboreal animals face additional challenges, as they must descend to the ground to cross roads (Soanes \& van der Ree, 2015). However, connectivity of habitat across roads, both natural and anthropogenic, can mitigate the negative effects of roads if arboreal animals traverse these connections (Van der Hoeven et al., 2010). There are relatively fewer data on how arboreal animals respond to roads in tropical forest regions, particularly for species found in rare tropical dry forests, which are amongst the world's most threatened ecosystems (Sagar \& Singh, 2006). Thus, hypothesis-driven studies are needed in the tropics to determine the impact of roads, rather than an a priori assumption of roads as barriers or vice versa.

Road ecology in Madagascar is particularly important because $94 \%$ of lemur taxa are currently listed by IUCN as threatened with extinction (Schwitzer et al., 2014) and expanding road construction may be a major cause of lemur habitat loss (Rogers et al., 2010), although there has been little empirical testing of this assumption. The lack of data is surprising given that roads bisect or border some of the largest and best-known protected areas on the island, such as Ranomafana and Ankarafantsika National Parks.

We investigated whether individual golden-brown mouse lemurs Microcebus ravelobensis were able to cross roads, and how their movement was affected in road environments with various levels of canopy connectivity and uninterrupted forest habitat along a national highway in Ankarafantsika National Park. We predicted that (1) individual lemurs would be able to cross roads when canopy connectivity was present, (2) individual lemurs in uninterrupted forests would not be hindered in their ability to move, and (3) there would be no significant effect of sex on the ability of lemurs to cross roads, as both males and females of the species disperse. These predictions were evaluated to test the hypothesis that roads were a barrier to movement in $M$. ravelobensis. 


\section{Methods}

We conducted a capture-mark-recapture study during the dry season (May-August) of 2015 in the Ampijoroa Forest Reserve within Ankarafantsika National Park. There are various microhabitats within the Park (Rakotondravony \& Radespiel, 2009), and Ampijoroa is characterized by infertile sandy soils with low water-holding capacities, gallery forest alongside Lake Ravelobe, and a high occurrence of non-native plantation trees, such as Mangifera indica and Tectona grandis (Rendigs et al., 2003; Crowley et al., 2012). Route Nationale 4 (RN4) is a $580 \mathrm{~km}$ two-lane paved highway from Antananarivo to Mahajanga, which runs directly through Ankarafantsika National Park in a north-south direction for c. $20 \mathrm{~km}$ (Fig. 1), dividing the Park into two sections, of 17,500 and 78,00o ha (Radespiel et al., 2008).

Mouse lemurs are small-bodied (30-70 g), nocturnal and solitary omnivores (Kappeler \& Rasoloarison, 2003). Individuals of our study species, $M$. ravelobensis, establish mixed-sex sleeping sites, their diets contain a higher percentage of arthropods, and they have a slightly sex-biased system of female philopatry, but both sexes disperse (Radespiel et al., 2003, 2008; Weidt et al., 2004). Previous

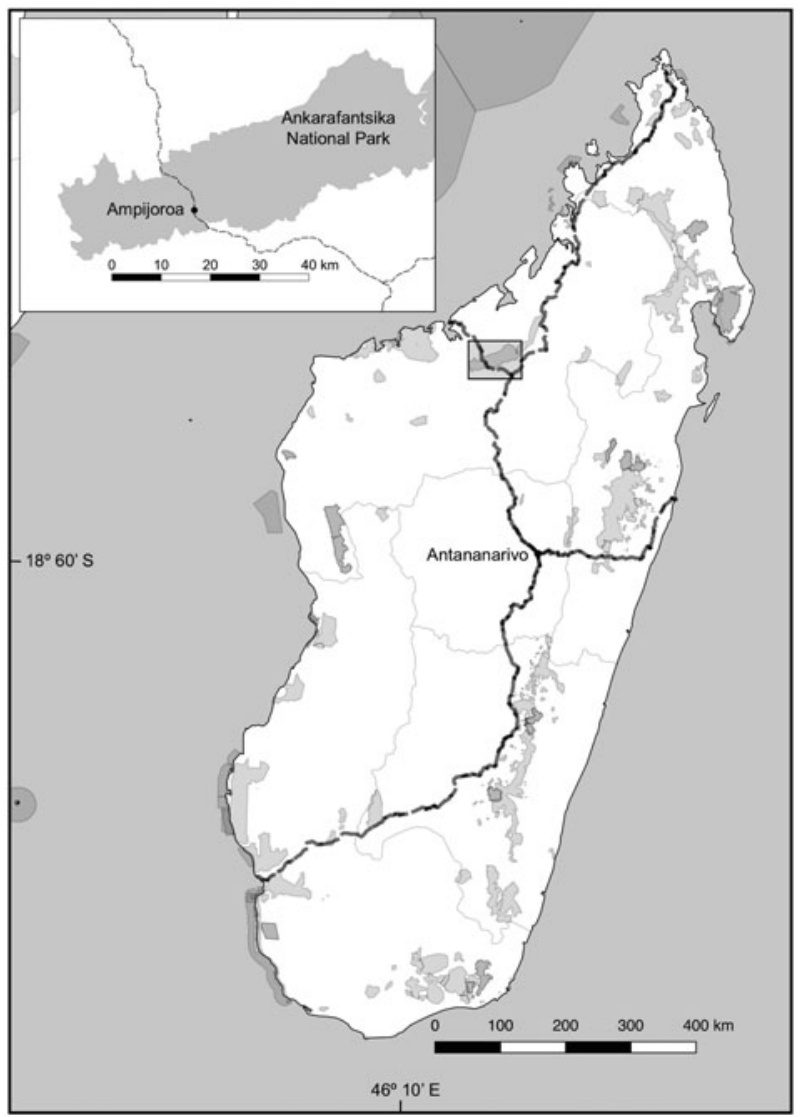

FIG. 1 Major national highways (dashed lines) and protected areas (grey shading) in Madagascar. The inset shows the division of Ankarafantsika National Park by Route Nationale $4\left(\mathrm{RN}_{4}\right)$ into areas of c. 17,500 and 78,00o ha. studies have suggested $M$. ravelobensis populations may be affected by roads, but because the road construction was relatively recent, no explicit genetic barrier was found (Radespiel et al., 2008). Mouse lemurs are excellent model organisms to distinguish between the direct and secondary effects of roads because they are under less direct hunting pressure than larger-bodied animals (Garcia \& Goodman, 2003).

We established six parallel trap lines of $475 \mathrm{~m}$ length at three locations in Ampijoroa (Fig. 1): two on either side of $\mathrm{RN}_{4}$ where there was canopy connectivity across the highway ( $\operatorname{Road} 1$ ), two on either side of $\mathrm{RN}_{4}$ at a site with no canopy connectivity (Road 2), and two within the interior forest, c. $1 \mathrm{~km}$ from the road or forest edge, as a control (Forest Control). We sampled trap lines on a 6-day randomized schedule; no trap line was sampled on 2 consecutive nights and monthly trapping intensity was equal at all sites.

We set live animal traps (Sherman, Tallahassee, USA) at $25 \mathrm{~m}$ intervals along each trap line, giving a total of 20 trapping sites per trap line and 40 traps at each location. We established the parallel interior transects at similar distances to those on the roads, c. $25 \mathrm{~m}$ apart. Upon capture, individuals were categorized by sex and age-class and were marked subcutaneously with a Trovan microchip. For a more detailed description of trapping procedures see Burke \& Lehman (2014). Our study was approved by the University of Toronto Office of Research Ethics (Protocol \#20011050) and complied with all legal requirements of Madagascar.

A crossing event was defined as when an individual was captured on one trap line and then recaptured on the parallel trap line. We used $t$-tests, $\chi^{2}$ tests, a one-way ANOVA, and Tukey's post-hoc analysis with $\alpha=0.05$ to test for differences in movement and capture rates between locations and sex categories. Movement was quantified by rounding distances between adjacent non-diagonal traps to $25 \mathrm{~m}$. All tests were performed in $R \quad$ v. 3.2.2 (R Development Core Team, 2013).

\section{Results}

We captured $120 M$. ravelobensis individuals in 1,032 capture events at the three locations over 2,245 trap nights $(2,520$ traps set, with 82 rodent captures and 144 trap malfunctions). There were no significant differences between trapping locations in terms of rates of rodent captures $(t=0.34, \mathrm{df}=60, \mathrm{P}=0.71)$ or trap malfunctions $(t=1.99$, $\mathrm{df}=60, \mathrm{P}=0.14)$. There were significantly more males caught at Road 1 and Road 2 than at Forest Control; males were also caught at a higher rate than females at Road 1 and Road 2, whereas at Forest Control there were no significant differences in the number of individuals caught by sex (Table 1). 
We found no significant differences in mean distance travelled by males and females at any of the three trapping locations (Fig. 1, Table 2). There was a significant difference in total movement between the three locations (Table 2). Tukey's post hoc analysis indicated there was a significant difference between Forest Control and $\operatorname{Road}_{1}(Q=5.68$, $\mathrm{df}=2,117, \quad \mathrm{P}<0.001)$ and Road $2(Q=7.78, \mathrm{df}=2,117$, $\mathrm{P}<0.01)$, but no significant difference between Roads 1 and $2(Q=2.21, \mathrm{df}=2,117, P>0.05)$.

We detected road crossing on 18 occasions, by 9 males (Table 3). Of these 18 captures, 14 (seven individuals) were at Road 1. At Road 2 we captured two individuals four times. Individuals $(n=5)$ at both locations were recaptured on their original trap line after being caught on the parallel line. At Forest Control we recaptured M. ravelobensis 157 times on a different trap line than that on which they were previously caught, corresponding to $77 \%(n=27$ of 35) of individuals.

\section{Discussion}

Our study is the first to directly test the permeability of roads to mammal movement in Madagascar, and our findings indicate that $\mathrm{RN}_{4}$ affects the movement of $M$. ravelobensis in Ankarafantsika National Park. Our first two predictions were validated: although the lemurs were able to cross $\mathrm{RN}_{4}$, they did so at a lower rate than if there had been undisturbed canopy. Thus, it is important for conservation managers to protect existing crossings and encourage more canopy growth, as our results suggest that crossing movement of $M$. ravelobensis would be further reduced if existing arboreal bridges were lost. However, Madagascar is prone to extreme climatic events, such as cyclones, droughts and wildfires (Ingram \& Dawson, 2005), and in

TABLE 1 Number of individuals captured (individuals identified and given a unique ID) and total number of captures (including recaptures) of golden-brown mouse lemurs Microcebus ravelobensis at the Road 1 (connection across $\mathrm{RN}_{4}$ ), Road 2 (no connection across $\mathrm{RN}_{4}$ ) and Forest Control (interior forest with no barrier) sites in the Ampijoroa Forest Reserve within Ankarafantsika National Park, Madagascar (Fig. 1), with $\chi^{2}$ and P (* denotes significance at $\mathrm{P}<0.05)$.

\begin{tabular}{lcllll}
\hline Location & Males & Females & $\chi^{2}$ & P & Total \\
\hline Individuals captured & & & & \\
Road 1 & 29 & 15 & 4.45 & $0.03^{*}$ & 44 \\
Road 2 & 28 & 13 & 6.25 & $0.01^{*}$ & 41 \\
Forest Control & 17 & 18 & 0.11 & 0.74 & 35 \\
Total & 74 & 46 & & & 120 \\
Total captures & & & & & \\
Road 1 & 177 & 101 & 20.78 & $0.01^{*}$ & 278 \\
Road 2 & 227 & 117 & 45.30 & $<0.01^{\star}$ & 344 \\
Forest Control & 183 & 227 & 2.36 & 0.31 & 410 \\
Total & 587 & 445 & & & 1,032 \\
\hline
\end{tabular}

TABLE 2 Distance moved ( \pm SD) by male and female individuals of M. ravelobensis at the Road 1 (connection across $\mathrm{RN}_{4}$ ), Road 2 (no connection across $\mathrm{RN}_{4}$ ) and Forest Control (interior forest with no barrier) sites in the Ampijoroa Forest Reserve (Fig. 1), with results of $t$-tests and ANOVA ( ${ }^{*}$ denotes significance $\left.\mathrm{P}<0.05\right)$.

\begin{tabular}{|c|c|c|c|c|c|}
\hline \multirow[b]{2}{*}{ Location } & \multicolumn{2}{|c|}{$\begin{array}{l}\text { Distance moved } \pm \mathrm{SD} \\
(\mathrm{m})\end{array}$} & \multirow[b]{2}{*}{$t$} & \multirow[b]{2}{*}{ df } & \multirow[b]{2}{*}{$\mathrm{P}$} \\
\hline & Males & Females & & & \\
\hline Road 1 & $123 \pm 144$ & $112 \pm 126$ & 0.26 & 42 & 0.79 \\
\hline Road 2 & $208 \pm 166$ & $175 \pm 203$ & 0.54 & 39 & 0.59 \\
\hline Forest Control & $299 \pm 220$ & $428 \pm 290$ & 1.48 & 33 & 0.15 \\
\hline Total & $183 \pm 182$ & $262 \pm 259$ & 16.25 & 2,117 & $<0.01^{\star}$ \\
\hline
\end{tabular}

2000 Cyclone Hudah resulted in the destruction of 51\% of trees and an $83 \%$ reduction in mean tree crown volume in the Masoala Peninsula (Birkinshaw \& Randrianjanahary, 2007). Cyclones of a similar nature and intensity occur in Ankarafantsika National Park (Aymoz et al., 2013). Additionally, if construction occurs along $\mathrm{RN}_{4}$, anthropogenic damage to these natural arboreal bridges may also occur (Weller, 2015). Thus, it would also be prudent for managers to investigate the efficacy of permanent anthropogenic crossing structures, such as bridges or culverts.

Our third prediction was not supported: only male $M$. ravelobensis were observed crossing $\mathrm{RN}_{4}$ and there were significantly more males alongside $\mathrm{RN}_{4}$ than within the interior forest. Although we captured significantly more males than females at Roads 1 and 2, we captured 15 and 13 individual females, respectively, over 100 times at each location. Additionally, at Forest Control we observed an equivalent number of crossings by males and females (13 and 14, respectively), and thus we consider our results to be robust. A sex-biased effect of roads has also been observed in North American freshwater turtles (Order Testudines), with female turtles more likely to be killed by vehicles than males while crossing roads to find nesting sites, leading to skewed sex ratios (Steen et al., 2006).

TABLE 3 The number of individuals of $M$. ravelobensis captured on both parallel trap lines (individuals crossing), and the total number of captures in which the previous capture was on the parallel trap line (crossing events), at the Road 1 (connection across RN4), Road 2 (no connection across $\mathrm{RN}_{4}$ ) and Forest Control (interior forest with no barrier) sites in the Ampijoroa Forest Reserve (Fig. 1).

\begin{tabular}{|c|c|c|c|c|c|c|}
\hline \multirow[b]{2}{*}{ Location } & \multicolumn{3}{|c|}{$\begin{array}{l}\text { No. of individuals } \\
\text { crossing }\end{array}$} & \multicolumn{3}{|c|}{ No. of crossing events } \\
\hline & Males & Females & Total & Males & Females & Total \\
\hline Road 1 & 7 & 0 & 7 & 14 & 0 & 14 \\
\hline Road 2 & 2 & 0 & 2 & 4 & 0 & 4 \\
\hline $\begin{array}{l}\text { Forest } \\
\text { Control }\end{array}$ & 14 & 13 & 27 & 70 & 87 & 157 \\
\hline Total & 23 & 13 & 36 & 88 & 87 & 175 \\
\hline
\end{tabular}


However, our results indicate that male $M$. ravelobensis are more likely to face mortality, as the crossing sex. Given that male and female $M$. ravelobensis have home ranges of equivalent size and both sexes disperse, this effect must be attributable to other factors, such as competition between males (Weidt et al., 2004) or home range pile-up, in which the lemurs are not affected by roads as direct barriers to dispersal, but through many individual or group home ranges abutting roads (Riley et al., 2006). This phenomenon can have significant genetic and social consequences in gregarious species such as mouse lemurs.

Our results on the roadside movement of $M$. ravelobensis are some of the first such data available for mammals in Madagascar, and contribute valuable data on the effects of roads on the understudied guild of arboreal mammals, for which research is especially needed in tropical environments such as Madagascar (Lehman et al., 2016). Managers of protected areas such as Ankarafantsika that are intersected or abutted by roads should investigate the efficacy of mitigation measures such as bridges or culverts (Smith et al., 2015) in aiding the movement of wildlife. However, anthropogenic bridges are potentially costly for developing nations, and have shown mixed results in aiding movement across barriers in Madagascar specifically (Mass et al., 2011). Our results suggest that natural bridges can aid movement, but further study comparing the efficacy of natural and anthropogenic bridges along $\mathrm{RN}_{4}$ and other roads in Madagascar is needed to clarify which is more effective. Given the urgent conservation needs and the rapid development of roads within Madagascar, more hypothesis-driven studies are needed on the effects of roads, to inform conservation initiatives.

\section{Acknowledgements}

We thank the staff of Madagascar Institute pour la Conservation des Environnements Tropicaux, Madagascar National Parks and La Maison du Pyla. We also thank Becky Raboy, Ute Radespiel, Elke Zimmerman, Jhonny Kenedy, Hajanirina Ravelonjanahary, Annette Klein, Mamy Rina Evasoa and Alida Hasiniaina for theoretical and practical assistance, and Amy Mui and two anonymous reviewers for valuable comments on this article. Funding for this study was provided by Primate Conservation Inc., Sigma Xi Grants-in-Aid of Research, University of Toronto Department of Anthropology, and Natural Science and Engineering Research Council of Canada grants to SML (Discovery Grant) and MSR (CGS-M).

\section{Author contributions}

MSR conducted all data analysis and drafted the article. MSR and AR collected the data, assisted by SML. AR and
SML assisted in designing the study and preparing the article.

\section{References}

Aymoz, B.G.P., Randrianjafy, V.R., Randrianjafy, Z.J.N. \& KHASA, D.P. (2013) Community management of natural resources: a case study from Ankarafantsika National Park, Madagascar. Ambio, $42,767-775$.

Birkinshaw, C. \& Randrianjanahary, M. (2007) The effects of Cyclone Hudah on the forest of Masoala Peninsula, Madagascar. Madagascar Conservation and Development, 2, 17-20.

Burke, R.J. \& LEHMAN, S.M. (2014) Edge effects on morphometrics and body mass in two sympatric species of mouse lemurs in Madagascar. Folia Primatologica, 85, 277-291.

Crowley, B.E., McGoogan, K.C. \& Lehman, S.M. (2012) Edge effects on foliar stable isotope values in a Madagascan tropical dry forest. PLoS ONE, 7(9), e44538.

Forman, R.T.T., Sperling, D., Bissonette, J.A., Clevenger, A.P., Cutshall, C.D., D Ale, V.H. et al. (2003) Road Ecology: Science and Solutions. Island Press, Washington, DC, USA.

Garcia, G. \& Goodman, S.M. (2003) Hunting of protected animals in the Parc National d'Ankarafantsika, north-western Madagascar. Oryx, 37, 115-118.

Holderegger, R. \& Di Giulio, M. (2010) The genetic effects of roads: a review of empirical evidence. Basic and Applied Ecology, 11, 522-531.

Ingram, J.C. \& Dawson, T.P. (2005) Climate change impacts and vegetation response on the island of Madagascar. Philosophical Transactions of the Royal Society: Mathematical, Physical and Engineering Sciences, 363, 55-59.

Kappeler, P. \& Rasoloarison, R.M. (2003) Microcebus, mouse lemurs, Tsidy. In The Natural History of Madagascar (eds S. M. Goodman \& J. Benstead), pp. 1310-1315. University of Chicago Press, Chicago, USA.

Lehman, S.M., Radespiel, U. \& Zimmermann, E. (2016) Conservation biology of the Cheirogaleidae: future research directions. In The Dwarf and Mouse Lemurs of Madagascar (eds S. M. Lehman, U. Radespiel \& E. Zimmermann), pp. 520-540. Cambridge University Press, Cambridge, UK.

Mass, V., Rakotomanga, B., Rakotondratsimba, G., Razafindramisa, S., Andrianaivomahefa, P., Dickinson, S. et al. (2011) Lemur bridges provide crossing structures over roads within a forested mining concession near Moramanga, Toamasina Province, Madagascar. Conservation Evidence, 8, 11-18.

R Development Core Team (2013) R: A Language and Environment for Statistical Computing. R Foundation for Statistical Computing, Vienna, Austria.

Radespiel, U., Ehresmann, P. \& Zimmermann, E. (2003) Species-specific usage of sleeping sites in two sympatric mouse lemur species (Microcebus murinus and M. ravelobensis) in northwestern Madagascar. American Journal of Primatology, 59, 139-151.

Radespiel, U., Rakotondravony, R. \& Chikhi, L. (2008) Natural and anthropogenic determinants of genetic structure in the largest remaining population of the endangered golden-brown mouse lemur, Microcebus ravelobensis. American Journal of Primatology, $70,860-870$.

Rakotondravony, R. \& Radespiel, U. (2009) Varying patterns of coexistence of two mouse lemur species (Microcebus ravelobensis and M. murinus) in a heterogeneous landscape. American Journal of Primatology, 71, 928-938. 
Rendigs, A., Radespiel, U., Wrogemann, D. \& Zimmermann, E. (2003) Relationship between microhabitat structure and distribution of mouse lemurs (Microcebus spp.) in northwestern Madagascar. International Journal of Primatology, 24, 47-64.

Riley, S.P.D., Pollinger, J.P., Sauvajot, R.M., York, E.C., Bromley, C., Fuller, T.K. \& Wayne, R.K. (2006) A southern California freeway is a physical and social barrier to gene flow in carnivores. Molecular Ecology, 15, 1733-1741.

Rogers, H.M., Glew, L., Honzák, M. \& Hudson, M.D. (2010) Prioritizing key biodiversity areas in Madagascar by including data on human pressure and ecosystem services. Landscape and Urban Planning, 96, 48-56.

SAGAR, R. \& Singh, J.S. (2006) Tree density, basal area and species diversity in a disturbed dry tropical forest of northern India: implications for conservation. Environmental Conservation, 33, 256-262.

Schwitzer, C., Mittermeier, R.A., Johnson, S.E., Donati, G., Irwin, M., PeAcock, H. et al. (2014) Averting lemur extinctions amid Madagascar's political crisis. Science, 343, 842-843.

Smith, D.J., van der Ree, R. \& Rosell, C. (2015) Wildlife crossing structures: an effective strategy to restore or maintain wildlife connectivity across roads. In Handbook of Road Ecology (eds R. van der Ree, D.J. Smith \& C. Grilo), pp. 172-183. John Wiley \& Sons, Chichester, UK.

Soanes, K. \& VAn der Ree, R. (2015) Reducing road impacts on tree-dwelling animals. In Handbook of Road Ecology (eds R. van der Ree, D.J. Smith \& C. Grilo), pp. 334-340. John Wiley \& Sons, Chichester, UK.
Steen, D.A., Aresco, M.J., Beilke, S.G., Compton, B.W., Condon, E.P., DodD, JR, C.K. et al. (2006) Relative vulnerability of female turtles to road mortality. Animal Conservation, 9, 269-273.

Van der Hoeven, C.A., de Boer, W.F. \& Prins, H.H.T. (2010) Roadside conditions as predictor for wildlife crossing probability in a Central African rainforest. African Journal of Ecology, 48, 368-377. van der Ree, R., Smith, D.J. \& Grilo, C. (2015) Handbook of Road Ecology. John Wiley \& Sons, Chichester, UK.

Weidt, A., Hagenah, N., Randrianambinina, B., Radespiel, U. \& Zimmermann, E. (2004) Social organization of the golden brown mouse lemur (Microcebus ravelobensis). American Journal of Physical Anthropology, 123, 40-51.

Weller, C. (2015) Construction of roads and wildlife mitigation measures: pitfalls and opportunities. In Handbook of Road Ecology (eds R. van der Ree, D.J. Smith \& C. Grilo), pp. 6o-64. John Wiley \& Sons, Chichester, UK.

\section{Biographical sketches}

MALCOLM RAmSAY's research focuses on lemur adaptations to complex anthropogenic environments. He is also interested in outcomes of applied conservation biology research in Madagascar and elsewhere. Andriamahery Razafindrakoto works on Microcebus as a model organism for primate biology, behaviour and health. SHAWN LEHMAN's long-term research objective is to integrate evolutionary ecology and conservation biogeography to model responses of primates to anthropogenic disturbances. 